\title{
Uit die hemel en hel Joan Hambidge
}

\section{Enantiodromia}

Ek is 'n gedig

wat'n plek

soek om te gebeur:

op my psige ingebreek

deur klouterdiewe

van die digkuns.

My paspoort en ID

raak soek as ek vra:

wié roep daar?

Op reis in 'n sirkelgang

weet ek nou

jy sal klip uit bloed tap.

'n Orkaan waai

die huis van die gedig

hermeties onderstebo:

Jannie Smuts dra

in sy saalsak

Kantwerk -

wolf, wolf

blaas blaas

voor die deur:

$E=\frac{m c^{2}}{2}$

word eerder mana (sic!)

uit die hemele

van die onbewuste

soos Carl Gustav

dit netjies stel:

complexio oppositorum

hou my dag en nag

tobbend oor oorgange:

dié bostaande formule

onbegrypend nes 'n akker

breek in my gemoed:

gedagvaar deur die dood en verloën oor die liefde,

dus as hermiet verban.

Die spreker (én leser)

bly skuilhou én kopkrap in die

kelders van onthou.

\section{Katabasis}

"We live life forwards and think about it backwards"

Howard Nemerov

Dieper delwend die verlede in

lesend aan die vyfde edisie

van die Norton

ontdek

ek 'n vers van Simon Armitage

oor hoe jy nooit'n gil

kan stilmaak nie.

Verder die hel in

speel skeeloog Sartre

harpsikord

en sing vals-vals

die hel-is-ander-mense;

met Dowe Peet

aan't klippe kap

oor sy weggegaan het

en bly merels voer

teen die wind;

nes Dirk-der-duisende

weet daar is moer

in sy grootkoffieboek

se digterlike parade.

Is ek dan steeds Orpheus

soekend na Eurydice

of word dié proses

meer-en-meer

'n anabasis?

What the hell!

Jeroen Bosch trip-

tiek ' $n$ laaste oordeel

met sy visies

van die helnaarmaals.

Op my ou ramkietjie

met net een snaar

speel ek immer op papier

só aanmekaar.
Read online:

Scan this QR code with your smart phone or mobile device to read online.
Affiliation: ${ }^{1}$ Department of Afrikaans Literature and Creative Writing, University of Cape Town, South Africa

Email: joan.hambidge@uct.ac.za

Postal address: Private Bag X3, Rondebosch 7701, South Africa

How to cite this article: Hambidge, J., 2014, 'Uit die hemel en hel', Literator 35(2), Art. \#1066, 1 page.

http://dx.doi.org/10.4102/lit.v35i2.1066

Note: These poems also appear on the author's blog at: http://www.joanhambidge.blogspot.com

Copyright: (C) 2014. The Authors. Licensee: AOSIS OpenJournals. This work is licensed under the Creative Commons Attribution License. 